\title{
Recenzja
}

\section{Jerzy Kowalski, Stanowienie i rozwój konstytucyjnej państwowości $w$ Polsce, Wydawnictwo Uniwersytetu w Sankt Petersburgu, Sankt Petersburg 2010, ss. 326}

W ostatnim okresie rosyjski rynek wydawniczy nie poświęcał zbyt dużo uwagi problematyce polskiego prawa, w tym prawa konstytucyjnego. Tematyka polska była obecna w publikacjach prawnych, ale w kontekście prawno-porównawczym $\mathrm{z}$ reguły w piśmiennictwie dotyczącym rozwoju prawa europejskiego. Dlatego też z wielkim uznaniem należy odnotować fakt ukazania się w rosyjskim wydawnictwie (wydawnictwo Uniwersytetu w Sankt Petersburgu) monografii poświęconej polskiemu konstytucjonalizmowi. Autorem tej publikacji, zatytułowanej Stanowienie i rozwój konstytucyjnej państwowości w Polsce jest dr J. Kowalski, który wydając tę pozycję w Petersburskim Instytucie Prawnym pod redakcją profesora S. Komorowa, w istotny sposób wypełnił tę wydawniczą lukę.

Praca, ze względu na swoje całościowe podejście do omawianych zagadnień konstytucjonalizmu w Polsce, które to nigdy wcześniej nie było tak szeroko omawiane we współczesnej rosyjskiej bibliografii prawnej, jest bez wątpienia istotnym wkładem w tym zakresie.

Monografia składa się z pięciu rozdziałów (łącznie 326 stron) poprzedzonych wprowadzeniem. Pierwszy rozdział, zatytułowany Geneza polskiej państwowości, przybliża czytelnikowi początki polskiego XVIII-wiecznego konstytucjonalizmu, idee Konstytucji 3 maja, kulisy jej przyjęcia oraz znaczenie, jakie miała na dalsze losy Rzeczpospolitej. Autor podkreśla w tym przypadku wielokrotnie, że Konstytucja 3 maja była drugą Konstytucją pisaną po Konstytucji Stanów Zjednoczonych w ówczesnym świecie. Nadmienienie tego typu faktu dla polskiego czytelnika wydaje się być nieco zbędne (jest to dla nas ogólnie znane), ale w przypadku czytelnika niepolskiego, a zwłaszcza pochodzącego z Rosji, gdzie konstytucjonalizm pojawił się ponad 100 lat później, jest to jak najbardziej usprawiedliwione. Autor przybliżając treść Konstytucji 3 maja, wskazuje na jej podobieństwo w kontekście 
praw obywatelskich do francuskiej Deklaracji Praw Człowieka i Obywatela z 1789 r. Prezentuje jej znaczenie i pozycję w ówczesnej Europie. Dr J. Kowalski opiera się nie tylko na polskiej literaturze i opinii w tym zakresie polskich konstytucjonalistów, ale swoje uwagi odnosi również do myśli rosyjskich znawców problematyki, takich jak np. prof. W. J. Czechariny czy też prof. B. A. Straszuna.

Dalsza część pierwszego rozdziału poświęcona jest omówieniu zagadnień związanych z rozbiorem Rzeczpospolitej i jej losem w XIX w. Prezentując ten okres w dziejach naszej „ułomnej” państwowości, autor przybliża czytelnikowi rozwój „polskiego konstytucjonalizmu” w okresie zaborów, tj. przede wszystkim poprzez nawiązanie do Konstytucji Księstwa Warszawskiego (1807) oraz Konstytucji Królestwa Polskiego (1815). Pierwszy rozdział oprócz wątku polskiego również dość szeroko zajmuje się tematyką rozwoju konstytucjonalizmu w XVIII-XIX w. w całej Europie. Autor w kontekście spraw polskich przedstawia rozwój idei konstytucjonalizmu w innych państwach europejskich takich jak np. Francja, Niemcy, Belgia.

Drugi rozdział, zatytułowany Ewolucja polskiej konstytucyjnej państwowości w okresie międzywojennym (1918-1939) dotyka przede wszystkim charakterystyki 3 przedziałów czasowych wynikających z ówczesnych regulacji konstytucyjnych i dziejów Polski. Jako pierwszy okres porozbiorowy Polski autor omawia formowanie się parlamentarnej demokracji w latach 1918-1926. Charakteryzuje ówczesne siły i tendencje polityczne oraz przybliża fakty związane z przyjęciem Konstytucji z 17 marca 1921 r. Wskazuje na główne cechy Konstytucji marcowej, jej postanowienia oraz pozycję prawnoustrojową organów państwa pod jej rządami.

Przedstawia również główne postacie polityczne ówczesnej Rzeczpospolitej, między innymi Józefa Piłsudskiego, Romana Dmowskiego, Ignacego Daszyńskiego. Dalsza część tego rozdziału poświęcona jest przybliżeniu czytelnikowi okresu lat 1926-1935. Dr J. Kowalski dość obszernie omawia zmiany systemu parlamentarnego, jakie miały miejsce po przewrocie majowym, a podyktowane były zmianami Konstytucji, przeprowadzonymi 2 sierpnia 1926 r., które w efekcie doprowadziły do przyjęcia nowej Konstytucji 24 kwietnia 1935 r. Autor przedstawia główne cechy tej Konstytucji, stosowanie jej w latach 1935-1939 w Polsce i w okresie rządu emigracyjnego. Końcowa część tego rozdziału poświęcona jest sytuacji politycznej w okupo- 
wanej Polsce, roli Armii Krajowej i innych organizacji, znaczenia i funkcjonowania państwa podziemnego oraz wpływu ZSRR na nowe dzieje Polski.

Kolejny rozdział książki autor zatytułował Konstytucyjność polskiej państwowości w okresie władzy ludowej, który odnosi się przede wszystkim do spraw związanych z powstaniem Polski Ludowej, przyjęciem Konstytucji w 1952 r. i budowaniem państwowości typu socjalistycznego. Autor dość dokładnie przedstawia i omawia katalog praw, jakie przysługiwały obywatelom PRL, podkreślając jednak, że większość z nich nigdy nie była realizowana. Końcowa część tego rozdziału poświęcona została ewolucji polskiej państwowości na przełomie lat 80 i 90 ub. stulecia. Autor monografii wspomina w tym przypadku o roli i znaczeniu wydarzeń w Polsce w latach 1980-1981, o próbie wprowadzenia w PRL pewnych reform gospodarczych w końcu lat 80., a także o zmianach w Konstytucji, polegających między innymi na ustanowieniu Rzecznika Praw Obywatelskich, NSA czy też instytucji referendum. Samo zaś zakończenie tego rozdziału poświęcone jest zmianom ustroju przełomu lat 80 i 90 . związanych z ustaleniami wynikającymi z obrad Okrągłego Stołu oraz wynikami wyborów do Parlamentu w czerwcu 1989 r., co zaowocowało istotnymi zmianami w Konstytucji z 1952 r. i przyjęciu Małej Konstytucji w 1992 r.

Ostatnie dwa rozdziały monografii dotyczą już czasów współczesnych w odniesieniu do obowiązującej Konstytucji. Czwarty rozdział, zatytułowany Konstytucyjna państwowość Polski w dobie współczesnej, omawia kwestie związane z przyjęciem Konstytucji RP w 1997 r. i funkcjonowaniem organów parlamentarnych pod jej rządami. Autor szczególnie dużo miejsca poświęca w tym przypadku instytucji Prezydenta w dziejach Polski, nawiązując historycznie do porównań obecnych rozwiązań w tym zakresie ze wcześniejszymi prezydenturami, poczynając od wyboru pierwszego prezydenta w $1922 \mathrm{r}$.

Piąty, ostatni rozdział, noszący tytuł Europejsko-konstytucyjne tradycje świeckiego państwa $w$ Polsce $i$ Rosji, ma charakter prawnoporównawczy. Autor bowiem porównuje w tym zakresie rozwiązania prawne dotyczące swobody przekonań religijnych i wyznania w obu państwach poprzez prezentowanie stosownych przepisów prawnych, tak konstytucyjnych, jak i ustawowych, dowodząc występowania w obu państwach wolności konfesji, ale jednocześnie zachowania ich świeckiego charakteru, co w przypadku zwłaszcza wielowyznaniowej Rosji jest szczególnie ważne. 
Podsumowując należy stwierdzić, że książka dr J. Kowalskiego poświęcona zagadnieniom polskiego konstytucjonalizmu w odniesieniu do czytelnika rosyjskiego może być ważnym uzupełnieniem jego wiedzy o polskiej tradycji konstytucyjnej i o obecnych zasadach obowiązujących w tym zakresie w Polsce.

Jerzy Rychlik (Wyższa Szkoła Zarządzania i Prawa im. Heleny Chodkowskiej) 